\title{
Kvalita života mladších nemocných po prodělaném infarktu myokardu
}

\author{
Petra Fujanová, Milan Hromádka, Richard Rokyta, \\ Pavlína Mokrejšová, Ladislava Vodičková
}

Klíčová slova:

Behaviorální faktory

Infarkt myokardu

Kvalita života

Mladší osoby

Sekundární prevence

\begin{abstract}
SOUHRN
Východisko: Při péči o osoby po infarktu myokardu (IM) se do popředí cílených intervencí dostávají behaviorální a psychosociální faktory. Cílem studie bylo zmapovat tyto faktory u mladších osob v dostatečném časovém odstupu po provedené perkutánní koronární intervenci pro akutní infarkt myokardu s elevacemi úseku ST (STEMI).

Metody: Sledování zahrnovalo všechny mladší pacienty po STEMI (muži $\leq 50$ let, ženy $\leq 60$ let) z Kardiologické jednotky intenzivní péče FN Plzeň za období šesti měsícủ. Hodnotili jsme vybrané klinické a laboratorní parametry a relevantní anamnestické údaje. Půl roku po IM vyplnily sledované osoby anonymně náš originální dotazník mapující vývoj jejich chování, prožívání a kvalitu sexuálního života a dotazník kvality života WHOQOL-BREF.

Výsledky: Výsledný soubor ( $n=66)$ se skládal z 25 žen a 41 mužů průměrného věku 48 let. Na začátku sledování bylo 73 \% kuřáků, šest měsíců po IM nadále kouří 61 \% osob. Kontrola lipidogramu byla provedena pouze u $65 \%$, o možnosti absolvovat lázeňskou léčbu bylo aktivně informováno jen $53 \%$ pacientů. Sport provozuje př́ležitostně pouze 42 \% nemocných. Únavu a nedostatek energie po IM popisuje 50 \% pacientů, pocity smutku a beznaděje udává $29 \%$ nemocných. Pocit úzkosti subjektivně popisuje $75 \%$ osob. Obavu ze selhání při sexu vyjádřilo $42 \%$ a z dalšího IM během sexu 38 \% respondentů. Edukováno ohledně sexuální aktivity nebylo $61 \%$ osob.

Závěr: I přes nesporné pokroky v péči o nemocné s kardiovaskulárním onemocněním by neměly být opomíjeny psychosociální a behaviorální faktory následné péče a sekundární prevence.
\end{abstract}

\section{Úvod}

Kardiovaskulární onemocnění patří mezi nejčastější příčiny mortality a závažné morbidity populace. Mezi země s největším výskytem srdečních chorob patří i Česká republika. Tento alarmující počet přetrvává i přes pokroky $\checkmark$ prevenci, diagnostice a terapii srdečních onemocnění. $\checkmark$ dnešní době nalézáme kardiovaskulární onemocnění stále častěji u mladších věkových skupin, u nichž mohou hrát významnou roli kromě klasických rizikových faktorů aterosklerózy i psychosomatické vlivy. Současný způsob života vede u vnímavých jedinců k rozvoji deprese, která může významně zvyšovat kardiovaskulární riziko. Přesný mechanismus není znám. Stresové hormony spolu se zvýšenou hodnotou lipidů a nikotinem mohou vést ke vzniku předčasných aterosklerotických změn. Současně dochází k aktivaci koagulace se zvýšeným rizikem aterotrombózy. Dochází k dysbalanci autonomního nervového systému se zvýšením sympatikotonie a snížením tonu parasympatiku [1-3].

Pracuji již několik let na kardiologické jednotce intenzivní péče (KJIP) a zde se setkáváme stále častěji s mladšími pacienty prijímanými pro akutní infarkt myokardu (IM).
Proto jsme se v naší práci zaměřili na tuto věkovou skupinu a snažili se posoudit rizikový profil nemocných a možné změny kvality života po prodělaném infarktu myokardu. Zajímalo nás, zda prodělaný IM vedl ke změně vnímání životních hodnot, zda nastaly změny v osobním, pracovním a sexuálním životě. Zároveň jsme se snažili posoudit výskyt možné deprese.

\section{Metodika}

Do průzkumu jsme vybrali skupinu pacientů (muži do 50 let a ženy do 60 let), kteří byli hospitalizováni na KJIP pro akutní IM s elevacemi úseku ST, léčených primární $\mathrm{PCI}$ v období od 1. 6. 2011 do 1. 12. 2011. Během hospitalizace jsme tyto nemocné požádali o spolupráci a vysvětlili jim význam našeho průzkumu. U všech pacientů zjistil lékař rizikové faktory s ohledem na kardiovaskulární onemocnění a výskyt deprese v osobní či rodinné anamnéze. $V$ odstupu šesti měsíců jsme nemocné oslovili formou anonymního dotazníku. K posouzení kvality života jsme částečně použili standardizovaný WHO dotazník WHOQOL-BREF. Celkem bylo obesláno 80 pacientů, návratnost dotazníků byla $83 \%$ [4]. 


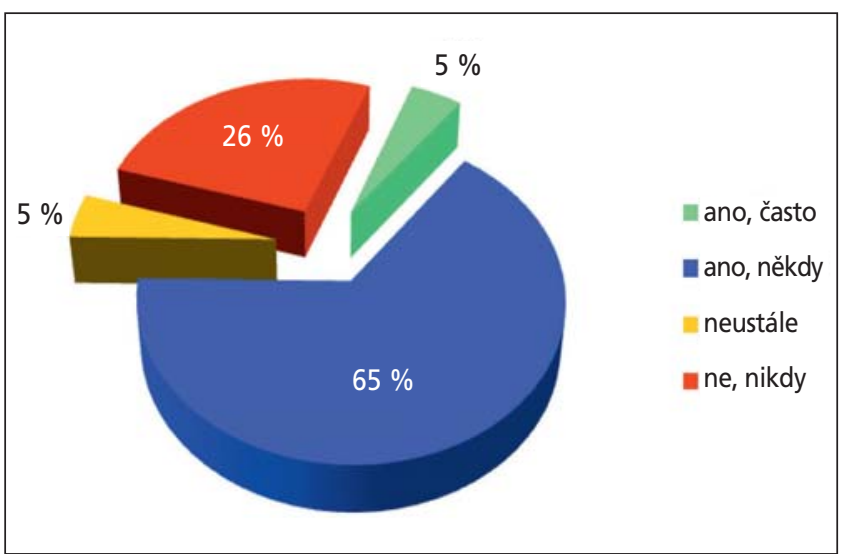

Obr. 1 - Vnímání úzkosti či deprese

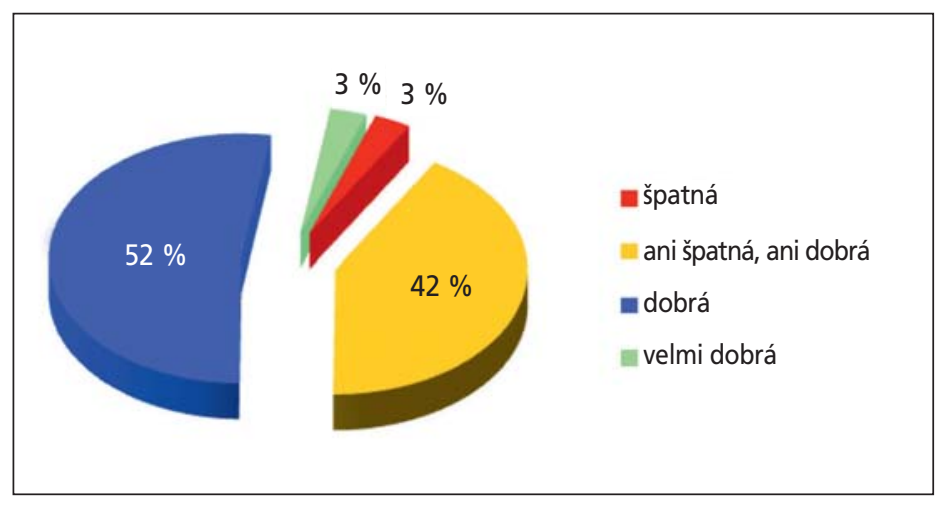

Obr. 2 - Hodnocení kvality vlastního života

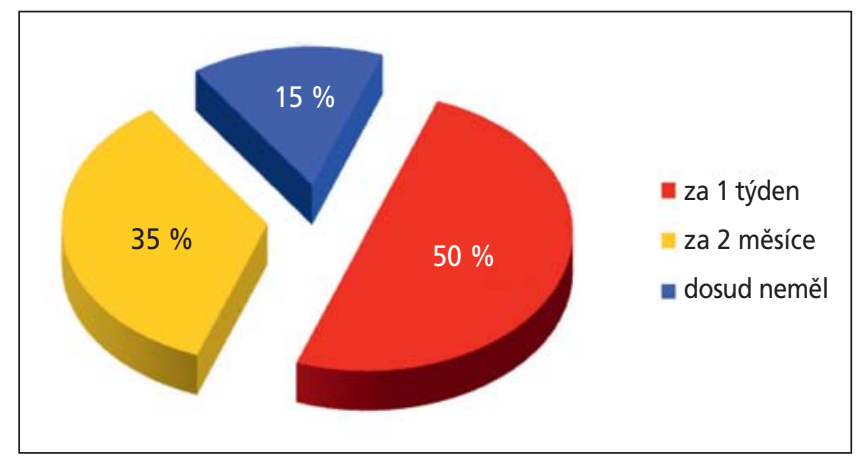

Obr. 3 - Sexuální aktivita po dimisi

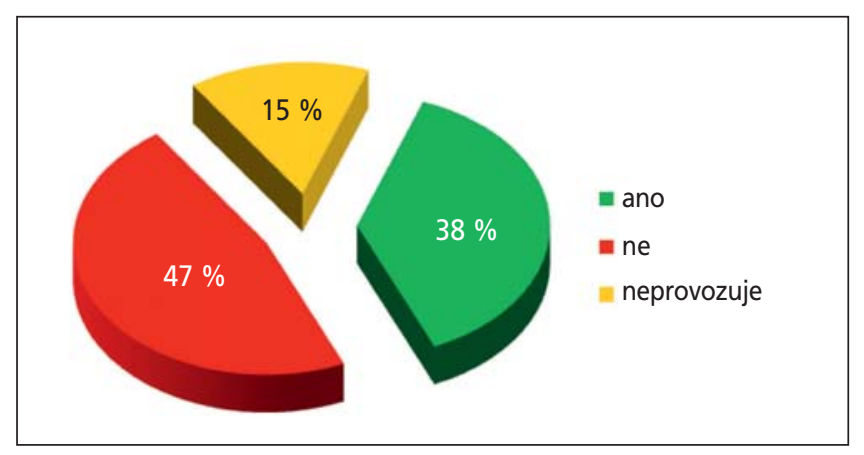

Obr. 4 - Obava z infarktu myokardu při sexu

\section{Výsledky a hodnocení}

Sledovaný soubor tvoří 66 pacientů, z toho 41 mužů (medián [interkvartilové rozpětí]) věku: 47 (42-49) let a 25 žen věku: 54 (48-56) let. Ve sledovaném souboru převažovali muži. Ženy tvořily 38 \% souboru. Většina pacientek byla v klimakteriu, kdy protektivní vliv estrogenů vyhasíná. $V$ rodinné anamnéze jsme pátrali po ischemické chorobě srdeční (ICHS). Za pozitivní rodinnou anamnézu jsme považovali výskyt infarktu myokardu, náhlé smrti nebo výskyt anginy pectoris u mužů do 45 let a u žen do 55 let. Zjistili jsme, že nebyl rozdíl mezi nemocnými stran pozitivní či negativní rodinné anamnézy. Pozitivní rodinnou anamnézu mělo $45 \%$ nemocných.

Kouření je jedním z hlavních rizikových faktorů, které ovlivňují rozvoj a průběh kardiovaskulárního onemocnění. $\checkmark$ našem souboru bylo $73 \%$ kuřáků. Po prodělaném infarktu myokardu pokračovalo v kouření $61 \%$ respondentů!

Arteriální hypertenze byla léčena u $48 \%$ pacientů před přijetím do nemocnice. Při přijetí byl zjištěn zvýšený krevní tlak u 44 \% pacientů. Z hlediska přežívání nemocných po IM je vyšší vstupní krevní tlak hodnocen spíše jako pozitivní, naopak vstupní hypotenze je spojena s horším prognózou nemocných.

Porucha tukového metabolismu představuje další významný rizikový faktor. $V$ našem souboru se dyslipidemie vyskytovala u $65 \%$ pacientů. Po šesti měsících nemělo $36 \%$ nemocných provedenu ošetřujícím lékařem kontrolu lipidogramu.

Posledním hodnoceným rizikovým faktorem byl diabetes mellitus 2. typu. Toto onemocnění se vyskytovalo pouze u $8 \%$ pacientů. Vstupní hyperglykemie byla přítomna u $42 \%$ pacientů, je často stresová, následující dny došlo $\mathrm{u}$ těchto nemocných $\mathrm{k}$ normalizaci hodnot.

A jak to bylo s nabídkou a realizací lázeňské léčby? Dle sdělení jen 53 \% nemocných bylo seznámeno praktickým lékařem s možností rehabilitace v lázních. Pobyt v lázních absolvovalo 48 \% nemocných. Z nich 75 \% hodnotí lázeňskou léčbu jako prospěšnou pro své zdraví.

Dále jsme sledovali ochotu změnit stravovací návyky. Dietu po IM nedodržovalo $27 \%$ nemocných. Pacienti nezařazovali do svého jídelníčku pravidelně zeleninu. Zařazení zeleniny do jídelníčku neprovádělo $50 \%$ nemocných. Ryby mělo ve svém jídelníčku $42 \%$ nemocných jednou ročně, $42 \%$ jednou měsíčně a pouze $13 \%$ jednou týdně. Pohybové aktivitě, jež je nedílnou součástí sekundární prevence po IM, se vůbec nevěnovalo $38 \%$ nemocných, $42 \%$ z dotázaných jen příležitostně $[2,3,5]$.

$\checkmark$ našem souboru až $65 \%$ nemocných po prodělaném IM pocituje úzkost či depresi (obr. 1). Sledovaní nemocní se nacházejí v produktivním věku. Spokojeno se svojí pracovní výkonností je pouze $46 \%$ pacientů. Kvalitu současného života hodnotí $52 \%$ nemocných jako dobrou, $42 \%$ ji nedokáže přesně ohodnotit (obr. 2) [5].

Součástí dotazníku bylo hodnocení sexuálního života. Polovina nemocných měla první sexuální styk do jednoho týdne po propuštění z nemocnice, 35 \% pacientů do dvou měsíců (obr. 3). Sexuální styk po šesti měsících nemělo $15 \%$ nemocných, i když v době před IM jejich život byl sexuálně aktivní. Pokles sexuální aktivity udávalo $38 \%$ nemocných. Obava z neuspokojení partnera se vyskytuje u $42 \%$ pacientů. Až $61 \%$ nemocných nebylo poučeno lé- 
kařem ohledně sexuální aktivity po prodělaném IM. Více než třetina nemocných se obává možného dalšího IM při sexuální aktivitě (obr. 4).

\section{Diskuse}

Hlavními rizikovými faktory sledovaného souboru mladších nemocných po IM je kuřáctví a dyslipidemie. V odstupu šesti měsíců jsme zjistili, že vysoké procento pacientů nadále kouří, přetrvává nízká ochota změnit stravovací návyky a provádět pravidelně pohybovou aktivitu. Př́ičinou může být nedostatečná edukace pacientů ze strany zdravotního personálu a též ne vždy aktivní přístup pacientů ke změně životního stylu. Řada nemocných v aktivním věku by mohla profitovat z lázeňské léčby, bohužel jim tuto možnost praktický lékař nenabídl. Někteři pacienti nabízenou lázeňskou péči odmítli z důvodu obav ze ztráty zaměstnání. Nemocní, kteří absolvovali lázeňský pobyt, jej hodnotí pozitivně z hlediska zlepšení jejich zdravotního i psychického stavu. Velké procento nemocných po infarktu myokardu trpí úzkostí a depresí, bohužel řadě z nich se nedostává pomoci, respektive ošetřující lékař toto nezjištuje [6]. Na těchto obtížích se mohou podílet i změny v sexuálním životě u stále aktivních osob. Nemocní pocitují nejen obavu z neuspokojení partnera, ale i obavu o své zdraví během pohlavního styku. Zlepšení edukace a psychologické podpory v této oblasti by mohlo pomoci. Někteří nemocní v produktivním věku nedokáží dostatečně eliminovat rizikové faktory, které přispívají $\mathrm{k}$ recidivě infarktu myokardu $[2,5]$.

\section{Závěr}

Mladší nemocní po infarktu myokardu jsou velmi rizikovou populací stran možné recidivy onemocnění, proto je nutné se maximálně soustředit na sekundární prevenci. Edukace pacientů by měla probíhat již na jednotkách intenzivní péče. Depresivní a úzkostné poruchy jsou často nedostatečně diagnostikovány, mohou mít vliv na další prognózu nemocných.

Podpořeno MZ ČR - RVO (Fakultní nemocnice Plzeň FNPI, 00669806).

Mgr. Petra Fujanová, Kardiologická JIP, Komplexní kardiovaskulární centrum, Fakultní nemocnice Plzeň, e-mail: FUJANOVA@fnplzen.cz

\section{Literatura}

[1] S. Býma, J. Hradec, Prevence kardiovaskulárních onemocnění, Novelizace 2009. Centrum doporučených postupů pro všeobecné praktické lékaře, SVL, Praha, 2009, s. 3-7.

[2] D. Hromadová, Kardiovaskulární onemocnění, Nakladatelství Neptun, Brno, 2004, s. 97-131.

[3] R. Špaček, P. Widimský, Infarkt myokardu, Galén, Praha, 2003, s. $39-70$.

[4] A. Dragomerická, J. Prajsová, WHOQOL-OLD, př́ručka pro uživatele české verze dotazníku, Protisk s.r.o., České Budějovice, 2009, s. 48-62.

[5] J. Kolář, et al., Kardiologie pro sestry intenzivní péče, Galén, Praha, 2009, s. 217-221.

[6] J. Křivohlavý, Psychologie nemoci, Grada Publishing, Praha, 2002, s.110-116. 